\title{
Synthetic Studies on ET 743. Asymmetric, Stereocontrolled Construction of the Tetrahydroisoquinoline Core via Radical Cyclization on a Glyoxalimine
}

\section{Dan Fishlock and Robert M. Williams}

Department of Chemistry, Colorado State University

Fort Collins, Colorado 80523-1872

University of Colorado Cancer Center, Aurora, Colorado 80045

rmw@lamar.colostate.edu

\section{Supporting Information}

\section{Experimental Details}

\section{Pages 1-8}

\section{NMR Spectra}

\section{Spectrum}

Compound $9{ }^{1} \mathrm{H}$ and ${ }^{13} \mathrm{C}$

Compound $11{ }^{1} \mathrm{H}$ and ${ }^{13} \mathrm{C}$

Page

Compound 11 VT experiment

Compound $3{ }^{1} \mathrm{H}$ and ${ }^{13} \mathrm{C}$

\section{Experimental Procedures}

General Procedures. ${ }^{1} \mathrm{H}$ and ${ }^{13} \mathrm{C}$ NMR spectra were obtained using Varian $300 \mathrm{MHz}$ or 400 $\mathrm{MHz}$ spectrometers, at room temperature unless otherwise stated. The chemical shifts are given in parts per million (ppm) relative to TMS at $\delta 0.00 \mathrm{ppm}$ or to residual $\mathrm{CHCl}_{3} \delta 7.24 \mathrm{ppm}$ for proton spectra and relative to $\mathrm{CDCl}_{3}$ at $\delta 77.0 \mathrm{ppm}$ for carbon spectra. Samples in toluene- $d 8$ are referenced to residual $\mathrm{PhCH}_{3}$ at $\delta 2.09 \mathrm{ppm}$ for proton spectra and relative to $\mathrm{C} 1$ of toluene- $d 8$ at $\delta 137.86$ ppm for carbon spectra. IR spectra were recorded on a Perkin-Elmer 1600 FTIR as thin films from $\mathrm{CH}_{2} \mathrm{Cl}_{2}$ on $\mathrm{NaCl}$ plates. Mass spectra were obtained using a Fisons VG Autospec spectrometer. Flash column chromatography was performed with silica gel grade 60 (230-400 mesh). Unless otherwise noted materials were obtained from commercially available sources and used without further purification. All reactions were performed under argon atmosphere. 


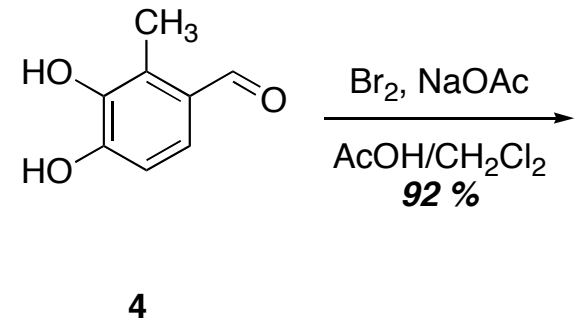<smiles>Cc1c(C=O)cc(Br)c(O)c1O</smiles>

5

5-bromo-3,4-dihydroxy-2-methylbenzaldehyde (5). Borchardt's catechol ${ }^{1} \mathbf{4}(15.20 \mathrm{~g}, 0.10$ mol) was dissolved in $\mathrm{AcOH}(50 \mathrm{~mL})$ and $\mathrm{CH}_{2} \mathrm{Cl}_{2}(50 \mathrm{~mL})$ at $0^{\circ} \mathrm{C}$, to which was subsequently added $\mathrm{NaOAc}(8.60 \mathrm{~g}, 0.105 \mathrm{~mol})$. Bromine $(5.2 \mathrm{~mL}, 0.101 \mathrm{~mol})$ was added drop-wise, and upon complete addition, the reaction mixture was allowed to warm to rt and stirred a total of $10 \mathrm{~h}$. The mixture was poured slowly into vigorously stirring water (1L) and stirred for $1 \mathrm{~h}$. Filtration provided a brown solid that was dried under vacuum $\left(70^{\circ} \mathrm{C}, 0.5 \mathrm{mmHg}\right)$ to provide the brominated product $5(12.90 \mathrm{~g})$. The aqueous filtrate was further extracted with $\mathrm{Et}_{2} \mathrm{O}(\mathrm{x} 2)$, and the combined organic fractions washed with brine, dried over $\mathrm{Na}_{2} \mathrm{SO}_{4}$ and filtered. Concentration and drying as above provided additional bromide $5(8.33 \mathrm{~g})$, for a total combined yield of $92 \%$. Both crops provided satisfactory ${ }^{1} \mathrm{H}$ NMR spectra and were used without further purification.

${ }^{1} \mathrm{H}$ NMR (300 MHz, Acetone- $d 6$,) $\delta 10.06$ (s, 1H), 9.00, (s, 1H), 8.27 (s, 1H), 7.57 (s, 1H), 2.54 (s, 3H).<smiles>Cc1c(C=O)cc(Br)c(O)c1O</smiles>

5

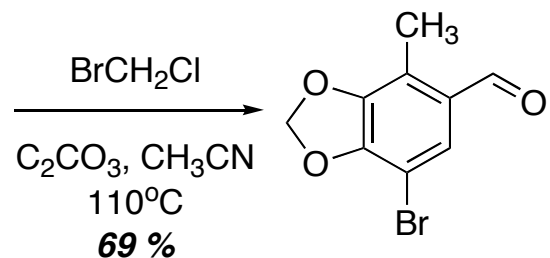

6

7-bromo-4-methylbenzo[d][1,3]dioxole-5-carbaldehyde (6). Catechol 5 (10.00 g, 43.29 mmol) was dissolved in dry $\mathrm{CH}_{3} \mathrm{CN}(200 \mathrm{~mL})$ in a sealable flask, to which $\mathrm{Cs}_{2} \mathrm{CO}_{3}(21.40 \mathrm{~g}, 64.94$ mmol) was added. The mixture was stirred at rt for $15 \mathrm{~min}$, and then $\mathrm{BrCH}_{2} \mathrm{Cl}(4.40 \mathrm{~mL}, 64.94$ mmol) was added. The flask was sealed and immersed in a $110^{\circ} \mathrm{C}$ oil bath for $24 \mathrm{~h}$. The reaction was cooled to rt and concentrated to provide a brown solid. This solid was suspended in EtOAc and passed through a short plug of silica gel to remove brown insoluble material. The filtrate was adsorbed onto silica gel and thoroughly dried before being purified by flash chromatography (5:1 
hexanes:EtOAc) to produce the methylenedioxy derivative $6(7.28 \mathrm{~g}, 69 \%)$ as of an off-white solid.

Rf 0.49 (5:1 Hexanes:EtOAc, UV, does not stain with PMA); M.p. 109-110 ${ }^{\circ} \mathrm{C}$ (EtOAc/Hexanes) IR (thin film) 1674, 1590, 1423, 1402, 1253, 1058, $935 \mathrm{~cm}^{-1}$.

${ }^{1} \mathrm{H}$ NMR $\left(300 \mathrm{MHz}, \mathrm{CDCl}_{3}\right) \delta 9.98(\mathrm{~s}, 1 \mathrm{H}), 7.52$ (s, 1H), 6.17 (s, 2H), $2.51(\mathrm{~s}, 3 \mathrm{H})$.

${ }^{13} \mathrm{C}$ NMR (100 MHz, $\left.\mathrm{CDCl}_{3}\right) \delta$ 190.1, 149.5, 147.5, 132.5, 130.7, 120.2, 102.2, 98.0, 11.4.

$\operatorname{HRMS}(\mathrm{FAB}+) \mathrm{m} / z$ calcd. for $\mathrm{C}_{9} \mathrm{H}_{7} \mathrm{BrO}_{3}(\mathrm{M})^{+} 241.9579 ; m / z$ found 241.9576 .

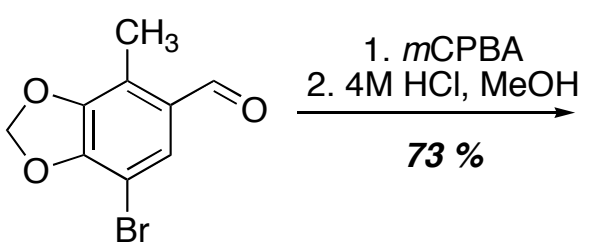

6

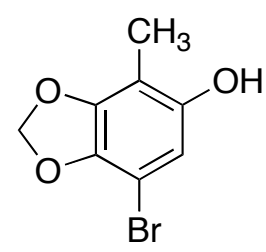

7

7-bromo-4-methylbenzo[d][1,3]dioxol-5-ol (7). To an ice cold solution of 6 (7.28 g, 30.0 $\mathrm{mmol})$ in $\mathrm{CHCl}_{3}(200 \mathrm{~mL})$ in a round bottom flask equipped with a reflux condenser was added mCPBA (12.9 g, $75.0 \mathrm{mmol})$. The mixture was stirred vigorously and brought to reflux for $3.5 \mathrm{~h}$, and then cooled to rt. The yellow solution was diluted with $\mathrm{CH}_{2} \mathrm{Cl}_{2}$ and then washed with a $5 \%$ solution of $\mathrm{NaHCO}_{3}(\mathrm{x} 4)$, brine, and then dried over $\mathrm{MgSO}_{4}$ and filtered. Evaporation of the solvent produced the formate intermediate as a highly crystalline yellow solid. ${ }^{1} \mathrm{H}$ NMR (300 $\left.\mathrm{MHz}, \mathrm{CDCl}_{3}\right) \delta 8.23(\mathrm{~s}, 1 \mathrm{H}), 6.70(\mathrm{~s}, 1 \mathrm{H}), 6.04(\mathrm{~s}, 2 \mathrm{H}), 2.00(\mathrm{~s}, 3 \mathrm{H})$. This solid was dissolved in $\mathrm{MeOH}(200 \mathrm{~mL})$ and $\mathrm{CH}_{2} \mathrm{Cl}_{2}(20 \mathrm{~mL})$ with vigorous stirring and then cooled to $0^{\circ} \mathrm{C}$. $4 \mathrm{M} \mathrm{HCl}$ $(50 \mathrm{~mL})$ was added and the mixture allowed to warm to rt over $1.5 \mathrm{~h}$. The clear yellow solution was diluted with brine and extracted with $\mathrm{CH}_{2} \mathrm{Cl}_{2}(\mathrm{x} 4)$. The combined organic fractions were washed with brine and then dried over $\mathrm{MgSO}_{4}$ and filtered. Flash chromatography (8:1 hexanes:EtOAc) provided 7 (5.03 g, 73\%) as an off-white solid.

Rf 0.43 (5:1 Hexanes:EtOAc, UV, PMA); M.p. $135-136^{\circ} \mathrm{C}$ (EtOAc/Hexanes)

IR (thin film) 3216, 1428, 1397, 1192, 1090, 1031, 939, $834 \mathrm{~cm}^{-1}$.

${ }^{1} \mathrm{H}$ NMR (300 MHz, $\left.\mathrm{CDCl}_{3}\right) \delta 6.39$ (s, 1H), 5.97 (s, 2H), 4.47 (s, 1H), $2.06(\mathrm{~s}, 3 \mathrm{H})$.

${ }^{13} \mathrm{C}$ NMR (100 MHz, $\left.\mathrm{CDCl}_{3}\right) \delta$ 149.6, 147.0, 139.4, 109.6, 107.1, 101.3, 96.5, 8.6.

HRMS(FAB+) $m / z$ calcd. For $\mathrm{C}_{8} \mathrm{H}_{7} \mathrm{BrO}_{3}(\mathrm{M})^{+} 229.9579 ; \mathrm{m} / \mathrm{z}$ found 229.9575 . 

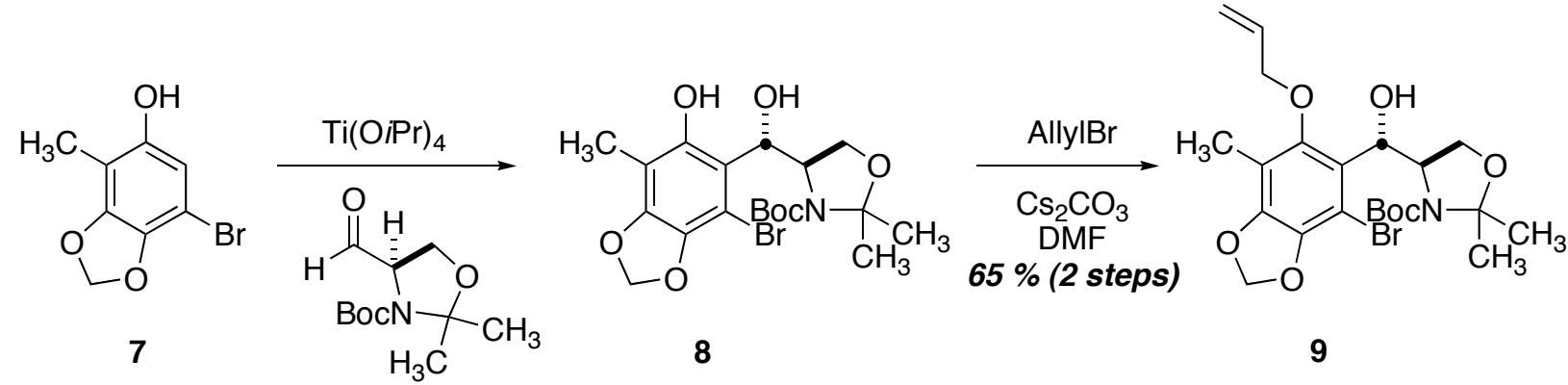

\section{(R)-tert-butyl 4-((S)-(6-(allyloxy)-4-bromo-7-methylbenzo[d][1,3]dioxol-5-} yl)(hydroxy)methyl)-2,2-dimethyloxazolidine-3-carboxylate (9).

Phenol 7 (3.00 g, $13.0 \mathrm{mmol})$ was added in one portion to a stirring solution of titanium(IV) isopropoxide $(3.90 \mathrm{~mL}, 14.3 \mathrm{mmol})$ in dry toluene $(120 \mathrm{~mL})$. The resulting red solution was distilled to half volume three times under an argon atmosphere in order to remove the resulting isopropanol, with the volume restored each time with fresh dry toluene. This red solution was cooled to $0^{\circ} \mathrm{C}$ and immersed in a sonicator filled with ice water. With vigorous sonication of the titanium phenolate solution under argon, a solution of $R$-Garner's aldehyde ${ }^{2}(3.87 \mathrm{~g}, 16.9 \mathrm{mmol})$ in toluene $(20 \mathrm{~mL})$ was added drop-wise over $30 \mathrm{~min}$. The reaction mixture was sonicated for $6 \mathrm{~h}$ while maintaining the temperature at $0-5^{\circ} \mathrm{C}$. The reaction was then allowed to warm to $\mathrm{rt}$ overnight $(16 \mathrm{~h})$ with stirring. The reaction was poured into a vigorously stirring aqueous solution of DL-tartaric acid and stirred for $1 \mathrm{~h}$, and then extracted with diethyl ether (x4). The combined ether extracts were washed with brine and dried over $\mathrm{Na}_{2} \mathrm{SO}_{4}$, filtered and concentrated to provide an orange oil. Purification by flash chromatography $5: 1$ hexanes:EtOAc) provided the diol 8 (4.78 g) of a pale yellow foam that was carried on to the next step.

By TLC the product has a virtually identical $\mathrm{Rf}$ as $R$-Garner's aldehyde, but the product stains strongly with $\mathrm{KMnO}_{4}$ and is UV active. $R$-Garner's aldehyde is not UV active and stains very weakly with $\mathrm{KMnO}_{4}$.

$\mathrm{Rf}=0.47\left(3: 1\right.$ hexanes:EtOAc, $\left.\mathrm{UV}, \mathrm{KMnO}_{4}\right) ; \mathrm{Rf}=0.19\left(5: 1\right.$ hexanes:EtOAc, $\left.\mathrm{UV}, \mathrm{KMnO}_{4}\right)$

HRMS(FAB+) $m / z$ calcd. for $\mathrm{C}_{19} \mathrm{H}_{26} \mathrm{O}_{7} \mathrm{~N}_{1} \mathrm{Br}(\mathrm{M})^{+} 459.0893 ; \mathrm{m} / \mathrm{z}$ found 459.0901 .

The diol 8 (4.78 g, $10.39 \mathrm{mmol})$ was suspended in DMF (30 mL), to which was added $\mathrm{Cs}_{2} \mathrm{CO}_{3}$ (6.77 g, $20.78 \mathrm{mmol})$ with stirring. Allyl bromide $(2.70 \mathrm{~mL}, 31.17 \mathrm{mmol})$ was added drop-wise and the reaction stirred for $2 \mathrm{~h}$ before being diluted with $\mathrm{Et}_{2} \mathrm{O}$ and $\mathrm{H}_{2} \mathrm{O}$. This mixture was extracted with $\mathrm{Et}_{2} \mathrm{O}(\mathrm{x} 4)$, and the combined organic fractions washed with brine (x2), and then dried over $\mathrm{MgSO}_{4}$, filtered and concentrated. Flash chromatography (5:1 hexanes:EtOAc) 
provided the allyl protected alcohol 9 (4.22 g, 65\% for two steps) as an oil that solidified to an off-white solid on standing.

Rf 0.17 (5:1 Hexanes:EtOAc, UV, $\left.\mathrm{KMnO}_{4}\right)$; M.p. 103-104 C (EtOAc/Hexanes)

$[\alpha]^{25}-25.4\left(\mathrm{c} 1.0, \mathrm{CH}_{2} \mathrm{Cl}_{2}\right)$

IR (thin film) 3458, 2977, 2934, 2880, 1694, 1386, 1365, $1099 \mathrm{~cm}^{-1}$.

${ }^{1} \mathrm{H}$ NMR (300 MHz, toluene-d8, 348K) $\delta 5.89$ (dddd, $\left.J=17.1,10.8,5.4,5.4 \mathrm{~Hz}, 1 \mathrm{H}\right), 5.33$ (m, 2H), $5.26(\mathrm{dq}, J=17.4,1.5 \mathrm{~Hz}, 1 \mathrm{H}), 5.26$ (d, $J=1.8 \mathrm{~Hz}, 1 \mathrm{H}), 5.04$ (dq, $J=10.5,1.5 \mathrm{~Hz}, 1 \mathrm{H})$, 4.51-4.57 (m, 1H), $4.48(\mathrm{dd}, J=9.3,1.2 \mathrm{~Hz}, 1 \mathrm{H}), 4.26-4.33(\mathrm{~m}, 2 \mathrm{H}), 3.75(\mathrm{dd}, J=9.0,5.7 \mathrm{~Hz}$, 1H), 1.98 (s, 3H), $1.79(\mathrm{~s}, 3 \mathrm{H}), 1.47(\mathrm{~s}, 3 \mathrm{H}), 1.26(\mathrm{~s}, 9 \mathrm{H})$.

${ }^{13} \mathrm{C}$ NMR (75 MHz, toluene-d8, 348K) $\delta 153.2,153.0,146.7,143.1,134.4,127.1,117.4,113.5$, $101.5,100.3,95.2,79.7,75.7,73.3,65.5,61.7,28.7$ (3C), 27.7, 24.5, 10.0.

HRMS(FAB+) $m / z$ calcd. For $\mathrm{C}_{22} \mathrm{H}_{30} \mathrm{BrNO}_{7}(\mathrm{M})^{+} 499.1206$; found 499.1193.

$\mathrm{C}_{22} \mathrm{H}_{30} \mathrm{BrNO}_{7}$ requires $\mathrm{C}, 52.81 ; \mathrm{H}, 6.04 ; \mathrm{N}, 2.80$. Found: $\mathrm{C}, 53.11 ; \mathrm{H}, 5.71 ; \mathrm{N}, 2.94$.

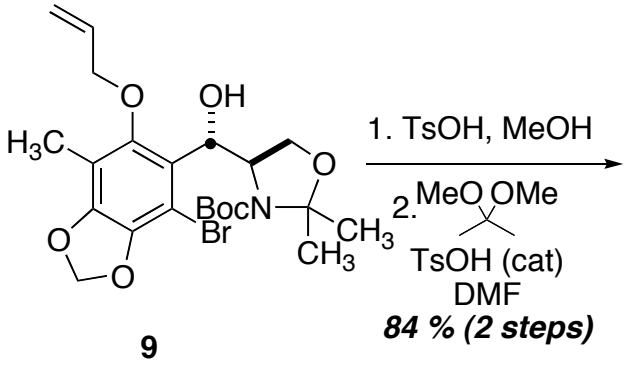

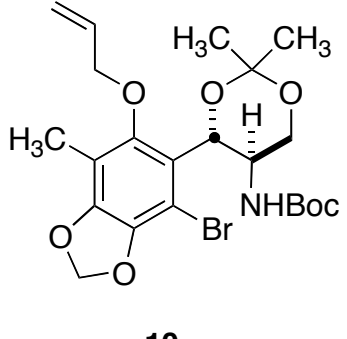

10
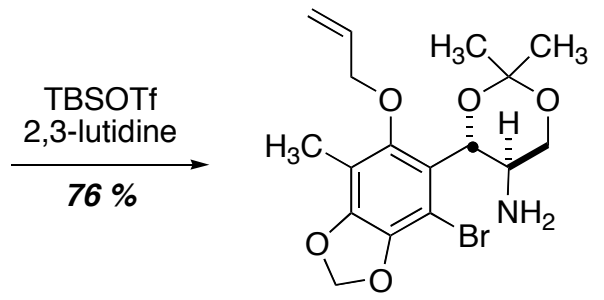

11

(4S,5R)-4-(6-(allyloxy)-4-bromo-7-methylbenzo[d][1,3]dioxol-5-yl)-2,2-dimethyl-1,3-dioxan-

5-amine (11). To a stirred solution of benzylic alcohol 9 (2.00 g, $4.00 \mathrm{mmol})$ in methanol (60 $\mathrm{mL})$ was added $\mathrm{TsOH} \cdot \mathrm{H}_{2} \mathrm{O}(76 \mathrm{mg}, 0.40 \mathrm{mmol})$ at $0^{\circ} \mathrm{C}$. The stirred solution was allowed to warm to rt over $5 \mathrm{~h}$, and then diluted with brine and extracted to $\mathrm{CH}_{2} \mathrm{Cl}_{2}(\mathrm{x} 3)$. The combined organic fractions were washed with brine and then dried over $\mathrm{MgSO}_{4}$, filtered and concentrated. The resulting foam was dissolved in DMF $(20 \mathrm{~mL})$ at $\mathrm{rt}$, to which was added $\mathrm{TsOH} \cdot \mathrm{H}_{2} \mathrm{O}(38 \mathrm{mg}$, $0.20 \mathrm{mmol})$, followed by 2,2-dimethoxypropane $(4.90 \mathrm{~mL}, 40.00 \mathrm{mmol})$. The resulting solution was stirred overnight (12 h) and then quenched with $\mathrm{NaHCO}_{3}$ (sat.) and extracted to $\mathrm{Et}_{2} \mathrm{O}$ (x3). The combined organic fractions were washed with brine and then dried over $\mathrm{MgSO}_{4}$, filtered and concentrated. Flash chromatography (5:1 hexanes:EtOAc) provided 10 (1.67 g, 84\% over 2 steps) as a pale yellow oil that was carried on to the next step.

$\mathrm{Rf}=0.29$ (5:1 Hexanes:EtOAc, UV, PMA). 
HRMS(FAB) calcd. for $\mathrm{C}_{22} \mathrm{H}_{30} \mathrm{O}_{7} \mathrm{NBr}(\mathrm{M})^{+}$499.1206; found 499.1190.

The $N$-Boc protected acetonide $10(1.67 \mathrm{~g}, 3.34 \mathrm{mmol})$ was dissolved in $\mathrm{CH}_{2} \mathrm{Cl}_{2}(30 \mathrm{~mL})$, to which was added 2,6 -lutidine $(0.78 \mathrm{~mL}, 6.68 \mathrm{mmol})$. This solution was cooled to $-78^{\circ} \mathrm{C}$ and TBSOTf $(0.85 \mathrm{~mL}, 3.76 \mathrm{mmol})$ was added drop-wise. The reaction was allowed to warm to $\mathrm{rt}$ over $3 \mathrm{~h}$ and then quenched with dry $\mathrm{MeOH}(2.0 \mathrm{~mL})$ and stirred for $15 \mathrm{~min}$. After concentration, the resulting oil was re-suspended in $\mathrm{MeOH}(25 \mathrm{~mL})$ and $\mathrm{KF} \bullet 2 \mathrm{H}_{2} \mathrm{O}(650 \mathrm{mg}, 6.68 \mathrm{mmol})$ was added with stirring. After $1 \mathrm{~h}$ of stirring, the solution was diluted with brine and then extracted with $\mathrm{CH}_{2} \mathrm{Cl}_{2}$ (x3). The combined organic fractions were washed with brine and then dried over $\mathrm{MgSO}_{4}$, filtered and concentrated. Flash chromatography (1:1 Hexanes:EtOAc with $\left.0.1 \% \mathrm{Et}_{3} \mathrm{~N}\right)$ provided the amine 11 (1.02 g, $76 \%$ ) of a clear, colorless oil that solidified on standing.

Rf 0.09 (streaks) (5:1 EtOAc:Hexanes, UV, $\mathrm{KMnO}_{4}$, ninhydrin); M.p. 99-100 ${ }^{\circ} \mathrm{C}$

(EtOAc/Hexanes)

$[\alpha]^{25}-1.4\left(\mathrm{c} 1.0, \mathrm{CH}_{2} \mathrm{Cl}_{2}\right)$

IR (thin film) 2990, 1459, 1419, $1102 \mathrm{~cm}^{-1}$.

${ }^{1} \mathrm{H}$ NMR (300 MHz, $\left.\mathrm{CDCl}_{3}\right) \delta$ 6.02-6.17 (m, 1H), 5.99 (s, 2H), $5.43(\mathrm{dq}, J=12.3,1.5 \mathrm{~Hz}, 1 \mathrm{H})$, 5.27 (br d, $J=7.8 \mathrm{~Hz}, 1 \mathrm{H}), 5.01$ (d, $J=7.2 \mathrm{~Hz}, 1 \mathrm{H}), 4.40-4.80$ (br s, 1H), 4.19 (dd, $J=9.3,4.5$ Hz, 1H), 3.98 (dd, $J=8.1,3.6 \mathrm{~Hz}, 1 \mathrm{H}), 3.82$ (br s, 1H), 3.57 (dd, $J=8.4,7.5 \mathrm{~Hz}, 1 \mathrm{H}), 2.11$ (s, 3H), 1.57 (s, 3H), 1.45 (s, 3H), 1.89 (br s, 1H).

The extremely broad allyl methylene peaks (4.40-4.80 and $3.82 \mathrm{ppm}$ ) are due to an allyl rotamer that was more clearly resolved with increased temperature $\left(85^{\circ} \mathrm{C}\right)$ in toluene- $d 8$ (see SI-2). The ${ }^{13} \mathrm{C} \mathrm{NMR}$ at $\mathrm{rt}$ in $\mathrm{CDCl}_{3}$ gave very broad and weak signals but a clean and sharp spectrum was obtained at $85^{\circ} \mathrm{C}$, also in toluene- $d 8$ :

${ }^{13} \mathrm{C}$ NMR (75 MHz, toluene-d8, 348K) $\delta 154.0,147.1,143.4,135.0,124.5,116.8,114.1,102.0$, 101.6, 99.8, 77.6, 76.0, 68.0, 48.3, 29.5, 20.0, 9.7.

$\mathrm{HRMS}(\mathrm{FAB}+) \mathrm{m} / z$ calcd. For $\mathrm{C}_{17} \mathrm{H}_{23} \mathrm{BrNO}_{5}(\mathrm{M}+\mathrm{H})^{+}$400.0760; found 400.0746.

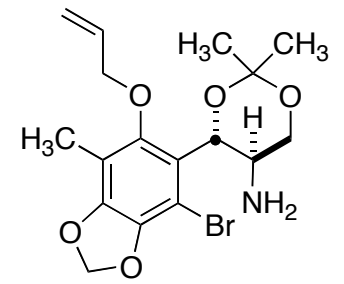

11

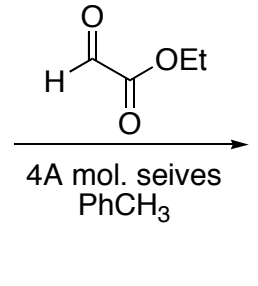

mol. seives

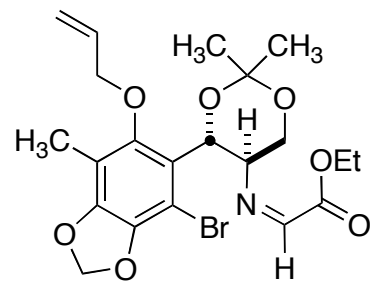

12

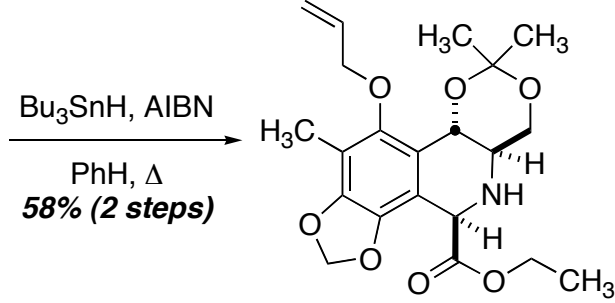

3 
$(4 R, 5 \mathrm{a} R, 9 \mathrm{a} S)$-ethyl 10-(allyloxy)-8,8,11-trimethyl-5,5a,6,9a-tetrahydro-4H-[1,3]dioxino[5,4c][1,3]dioxolo[4,5-h]isoquinoline-4-carboxylate:

(1,3-cis-tetrahydroisoquinoline) (3). Amine 11 (1.0 g, $2.50 \mathrm{mmol})$ was dissolved in dry toluene $(4.0 \mathrm{~mL})$, to which was added powdered $4 \AA$ molecular sieves $(600 \mathrm{mg})$ and ethyl glyoxalate (50\% solution in toluene, $700 \mu \mathrm{L}, \sim 3.5 \mathrm{mmol}$ ). This mixture was stirred at $\mathrm{rt}$ for $1 \mathrm{~h}$ and then filtered through celite, rinsing with dry $\mathrm{CH}_{2} \mathrm{Cl}_{2}$, into a $500 \mathrm{~mL}$ 3-neck round bottom flask. The solution was concentrated and dried under high vacuum to provide $\mathbf{1 2}$ as a clear, colorless oil [Rf 0.74 (streaks) (Hex:EtOAc 1:1, UV, $\left.\left.\mathrm{KMnO}_{4}\right)\right]$ which was used immediately in the radical closure.

In the 3-neck RBF equipped with a cold finger, condenser and inlet septum, the glyoxalimine 12 was dissolved in dry, degassed (freeze/pump/thaw x3) benzene (200 mL) and immersed in an oil bath set to $90^{\circ} \mathrm{C}$ under argon atmosphere. A solution of $\mathrm{Bu}_{3} \mathrm{SnH}(1.33 \mathrm{~mL}, 5.0 \mathrm{mmol})$ and AIBN (recrystallized from $\mathrm{MeOH})(495 \mathrm{mg}, 3.0 \mathrm{mmol})$ in degassed benzene $(20 \mathrm{~mL})$ was added to the solution drop-wise using a syringe pump over $5.5 \mathrm{~h}$. The reaction mixture was stirred for $1 \mathrm{~h}$ following complete addition, then cooled and concentrated. A ${ }^{1} \mathrm{H}$ NMR spectrum was acquired of the crude oil, that was subsequently purified by flash chromatography (1:1 hexanes:EtOAc) using silica gel containing $10 \%$ powdered $\mathrm{KF}^{3}$ The tetrahydroisoquinoline $3(591 \mathrm{mg}, 58 \%$ over 2 steps) was obtained as a white solid.

Recrystallization from $\mathrm{CH}_{2} \mathrm{Cl}_{2} /$ hex produced X-ray quality crystals that provided the relative stereochemistry at $\mathrm{C} 1$.

$\mathrm{Rf}=0.21$ (1:1 Hexanes:EtOAc, faint UV, $\mathrm{KMnO}_{4}$, PMA); M.p. $140-141^{\circ} \mathrm{C}\left(\mathrm{CH}_{2} \mathrm{Cl}_{2} / \mathrm{Hexanes}\right)$.

$[\alpha]^{25}-129.1\left(\mathrm{c} 1.0, \mathrm{CH}_{2} \mathrm{Cl}_{2}\right)$

IR (thin film) 2990, 1736, 1193, 1103, $1030 \mathrm{~cm}^{-1}$.

${ }^{1} \mathrm{H}$ NMR $\left(300 \mathrm{MHz}, \mathrm{CDCl}_{3}\right.$ ) $\delta 6.04(\mathrm{dddd}, J=17.2,10.5,5.1,5.1 \mathrm{~Hz}, 1 \mathrm{H}), 5.91(\mathrm{~d}, J=1.4 \mathrm{~Hz}$, $1 \mathrm{H}), 5.85(\mathrm{~d}, J=1.4 \mathrm{~Hz}, 1 \mathrm{H}), 5.40(\mathrm{dq}, J=17.2,1.8 \mathrm{~Hz}, 1 \mathrm{H}), 5.22(\mathrm{dq}, J=10.5,1.5 \mathrm{~Hz}, 1 \mathrm{H})$, $4.89(\mathrm{dd}, J=9.8,0.8 \mathrm{~Hz}, 1 \mathrm{H}), 4.82(\mathrm{br} \mathrm{s}, 1 \mathrm{H}), 4.37(1 / 2 \mathrm{ABq}, J=12.3 \mathrm{~Hz}$, further split as dt, $J=$ $5.1,1.8 \mathrm{~Hz}, 1 \mathrm{H}), 4.30(1 / 2 \mathrm{ABq}, J=12.3 \mathrm{~Hz}$, further split as dt, $J=5.1,1.8 \mathrm{~Hz}, 1 \mathrm{H}), 4.21$ (dq, $J$ $=7.2,2.7 \mathrm{~Hz}, 2 \mathrm{H}), 3.96(\mathrm{dd}, J=10.8,4.8 \mathrm{~Hz}, 1 \mathrm{H}), 3.81(\operatorname{app~t}, J=10.8 \mathrm{~Hz}, 1 \mathrm{H}), 2.87(\mathrm{~m}, 1 \mathrm{H})$, $2.13(\mathrm{~s}, 3 \mathrm{H}), 1.66$ (br s, 1H), $1.60(\mathrm{~s}, 3 \mathrm{H}), 1.47$ (s, 3H), 1.28 (t, J=7.2 Hz, 3H).

${ }^{13} \mathrm{C} \mathrm{NMR}\left(100 \mathrm{MHz}, \mathrm{CDCl}_{3}\right) \delta$ 171.4, 150.6, 145.7, 139.4, 134.2, 121.1, 115.9, 114.2, 112.0, $101.2,99.7,73.3,69.9,64.4,61.5,57.7,53.9,29.6,19.0,13.9,9.2$.

HRMS(FAB+) $m / z$ calcd. For $\mathrm{C}_{21} \mathrm{H}_{28} \mathrm{NO}_{7} \quad(\mathrm{M}+\mathrm{H})^{+}$406.1866; found 406.1852. 
${ }^{1}$ Sinhababu, A. K.; Ghosh, A. K.; Borchardt, R. T. J. Med. Chem. 1985, 28, 1273-1279.

${ }^{2}$ Garner, P.; Park, J. M. Org. Synth., 1992, 70, 18-28.

${ }^{3}$ Harrowven, D. C.; Guy, I. L. Chem. Commun. 2004, 1968-1969. 


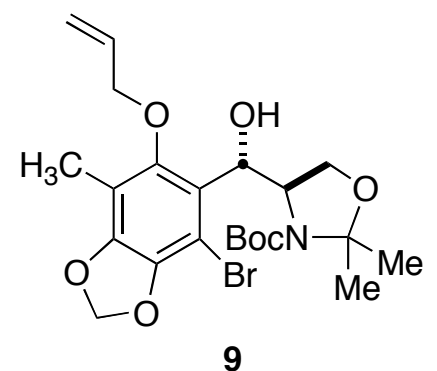

Toluene- $d 8,348 \mathrm{~K}$
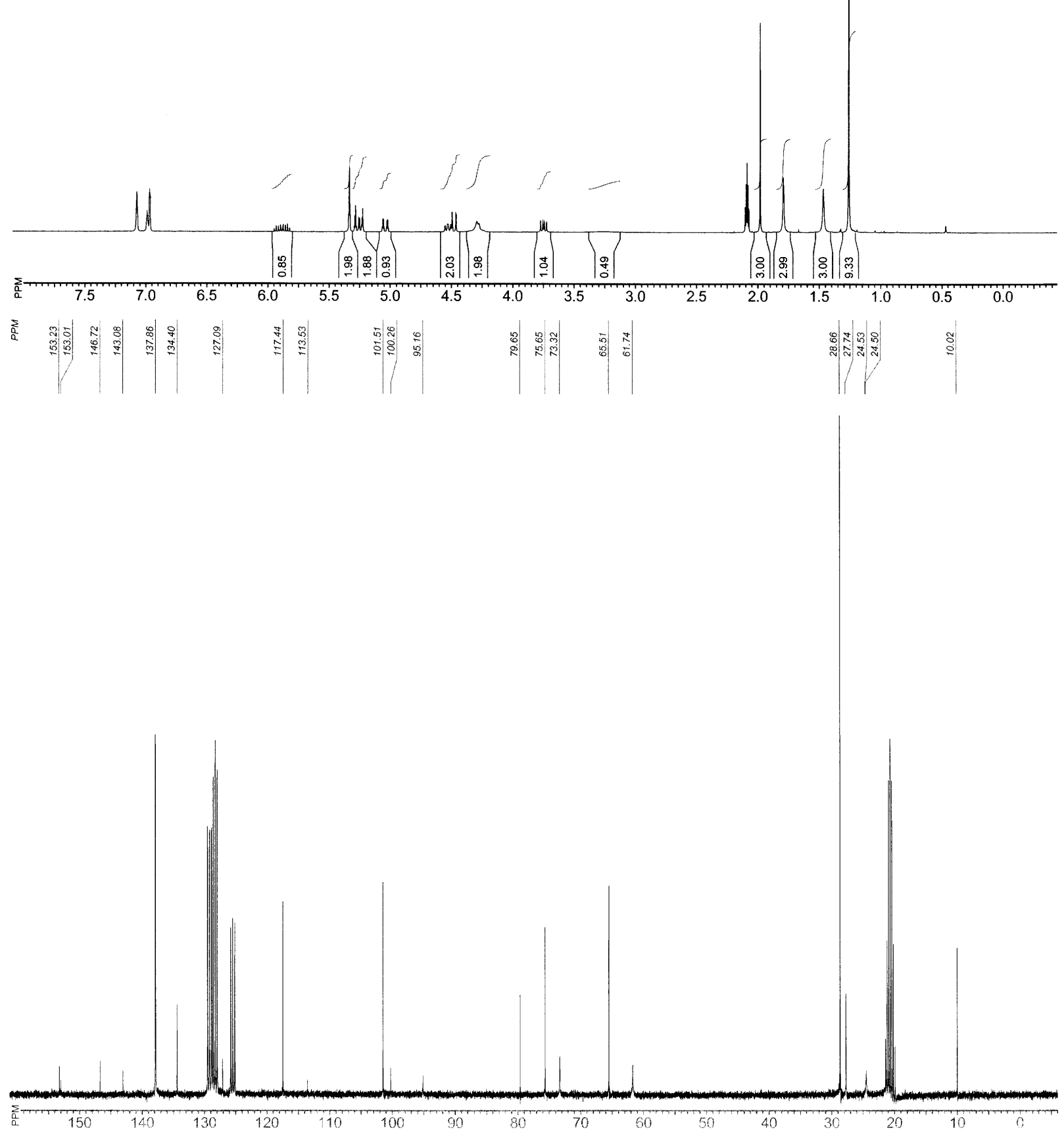

SI-9 


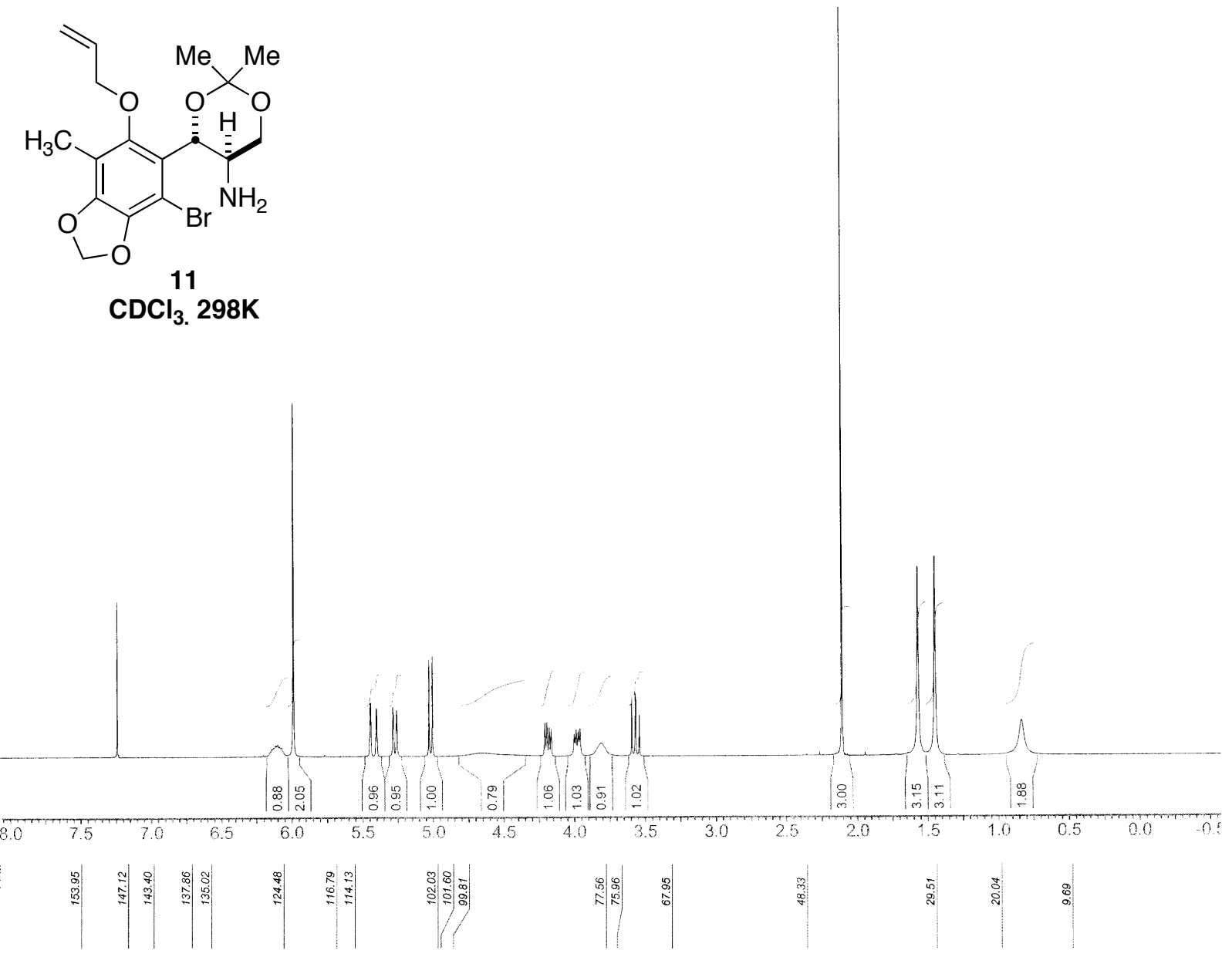

11

Toluene- $d_{8 .} 348 \mathrm{~K}$

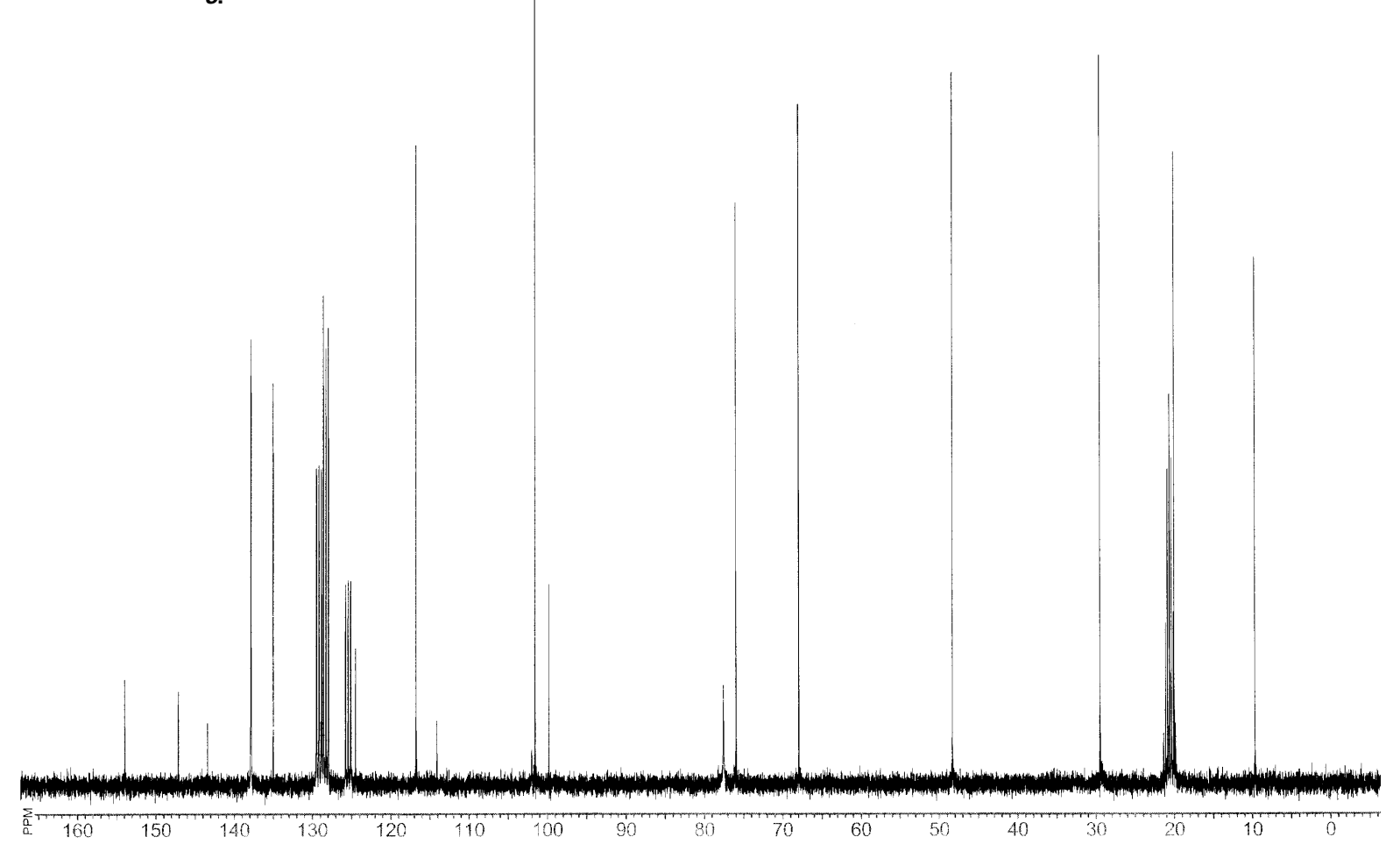

SI-10 
<smiles>C=CCOc1c(C)c2c(c(Br)c1[C@@H]1OC(C)(C)OC[C@H]1N)OCO2</smiles>

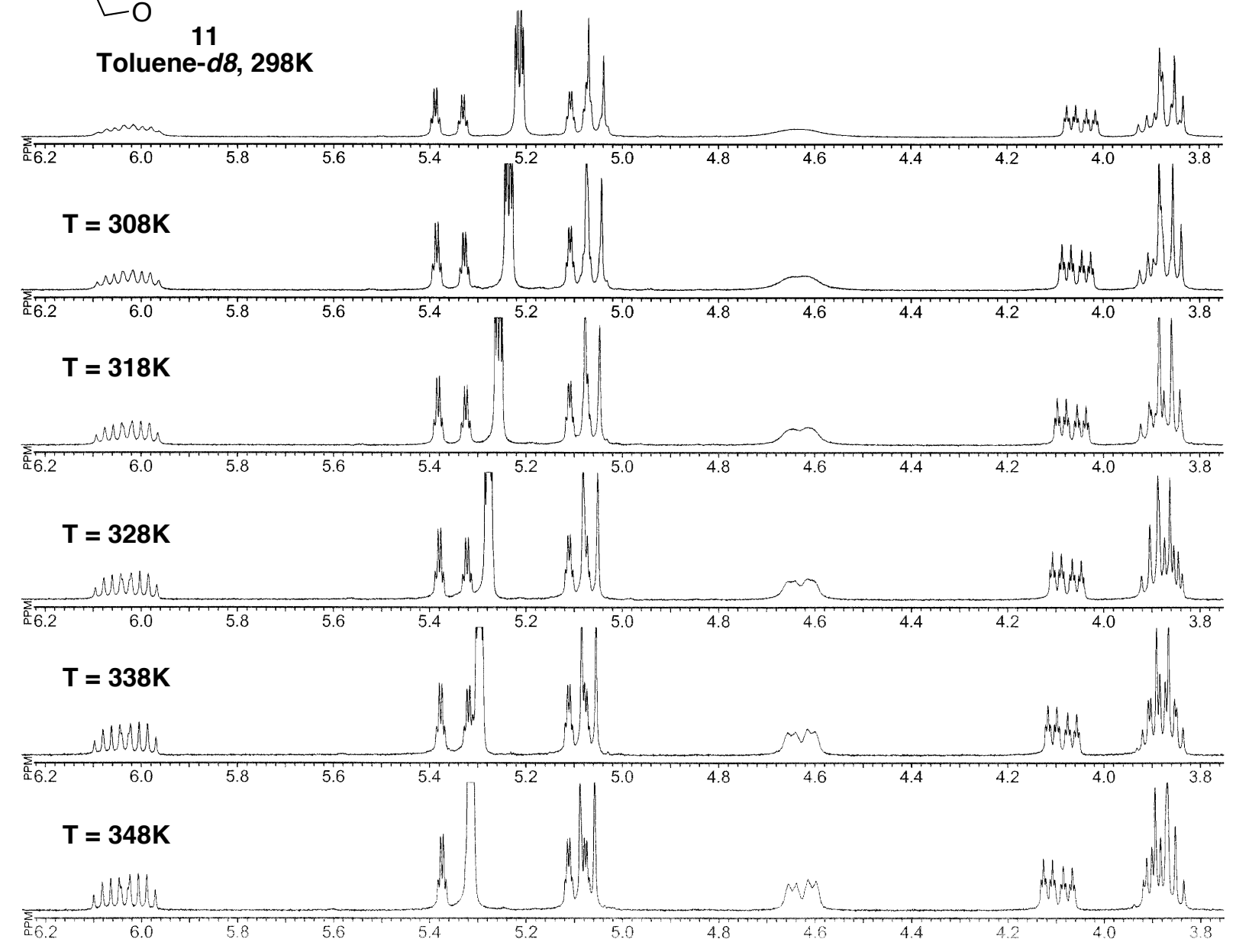



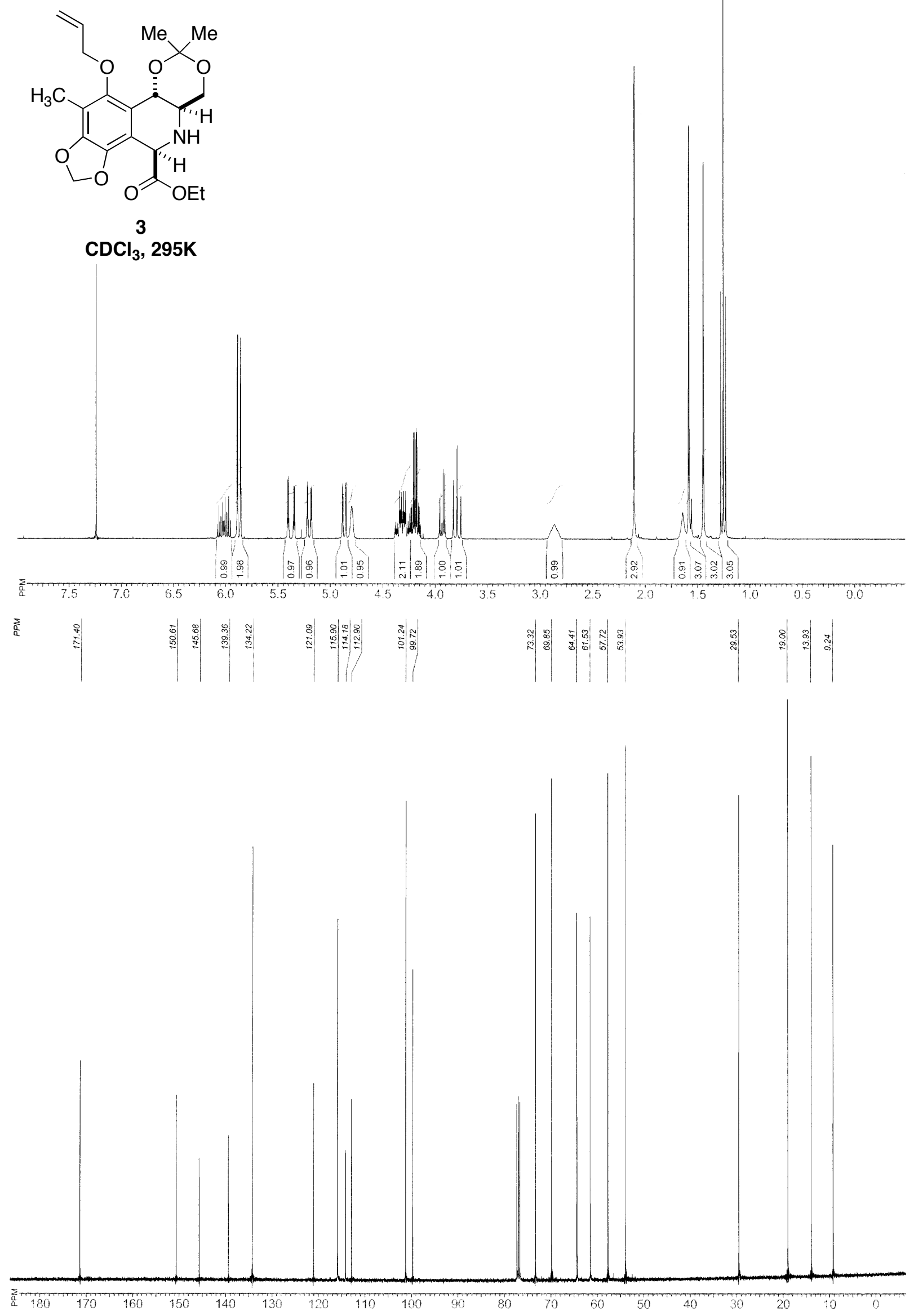

SI-12 